\title{
Hydromechanical Behavior of Soil with Tire Fibers
}

\author{
A.C. Silva, S. Fucale, S.R.M. Ferreira
}

\begin{abstract}
Products derived from tires have been increasingly used for geotechnical engineering applications because of the economic, environmental, and social benefits they provide. The objective of this paper is to analyze the effect of the addition of rubber fibers from unserviceable tires on the hydromechanical behavior of argillaceous soil from the Barreiras Formation, in the Brazilian northeast. Soil mixtures were prepared containing $10 \%$ and $20 \%$ tire fibers, by weight, at optimum moisture and maximum dry specific weight. Their microstructure, shear strength, and permeability were evaluated. The Scanning Electron Microscopy (SEM) analysis indicates changes in the soil microstructure from the addition of the fibers and there is an intense interaction of fiber with the soil matrix. There is an increase in the shear strength of the blends by up to $47 \%$, making them more ductile. The saturated hydraulic conductivity of the soil is in the order of $10^{-10} \mathrm{~m} / \mathrm{s}$, assuming values between $10^{-8}$ and $10^{-6} \mathrm{~m} / \mathrm{s}$ when the tire fibers are inserted into the structure.
\end{abstract}

Keywords: tire fibers, shear strength, permeability, soil-fiber interaction.

\section{Introduction}

The disposal of waste tires is a globally recognized problem. It is estimated that around 1.5 billion used tires are discarded annually worldwide (ETRMA, 2011). In the United States more than 233 million units were discarded in 2013 (RMA, 2014) and in Europe more than 3 million tons are generated annually (ETRA, 2013). In Brazil it is estimated that approximately 450 thousand tons of tires are discarded annually (SEST/SENAT, 2017).

Unserviceable tires are responsible for a number of problems when they are irregularly disposed near public places such as empty lots, water bodies and traffic routes, attracting the disposal of other wastes in these same environments and contributing to the proliferation of disease vectors. The alarming figures for illegal disposal and the problems related to the irregular dumping of tires have driven the development of methods for reusing or recycling both end-of-life tires and waste produced from used tires.

Pneumatic materials, due to their characteristics such as high durability, low density, and low water absorption, can be used in many Civil Engineering applications, such as leachate drainage systems for landfills, drainage layers for roads, reinforcement and improvement of soil support capacity, absorption of vibrations from railway lines, among others (Edinçliler \& Ayhan, 2010; Hazarika et al., 2010; Kaushik et al., 2015; Indraratna et al., 2018).

The inclusion of tire-derived materials into the soil has been the focus of several studies, such as reinforcement for road subsoil or as a component of fill material (Bosscher et al., 1997; Edinçliler \& Cagatay, 2013), light fill material for containment structures (Reddy \& Krishna, 2017; Moghadam et al., 2018), or as an asphalt additive (Xu et al.,
2017), due not only to the potential for finding an adequate destination for waste tires, but also because of the characteristics that these materials provide to the soil. Experimental results reported in the literature show that there are improvements to physical properties and to the tensionstrain behavior of soils that have been reinforced with pneumatic waste material (Ozkul \& Baykal, 2007; Tafreshi et al., 2012; Balunaini et al., 2014; Fu et al., 2014; Anvari et al., 2017).

Fibers added to soils can be either oriented in a preferential direction or randomly distributed. When in a random configuration, there is a reduction of fragile points, resistance isotropy in the soil-fiber mixture and a greater extensibility and ductility in the composite material (Edinçliler \& Cagatay, 2013). Another factor that affects the mixtures responses is the fiber content. Several studies have mixed soil with tire fibers in proportions ranging from $10 \%$ to $50 \%$, obtaining better mechanical response when kept within this range (Edinçliler \& Ayhan, 2010; Sellaf et al., 2014; Macedo et al., 2016).

Considering the high generation of non-repairable tires discarded annually in Brazil (SEST/SENAT, 2017) causing an environmental liability, the high resistance to decomposition over time by its constituents (Indraratna et al., 2018) and the possibility of including materials ground tire derivatives as reinforcement for the underground road or as a component of landfill material; this article analyzes the effect of the interaction of rubber tire fibers on the hydromechanical behavior of a soil in the Barreiras Formation, which is widely used as landfill material. The Barreiras Formation extends from Amapá to Rio de Janeiro (Veiga, 2014).

Aline Cátia da Silva, M.Sc., D.Sc. student, Departamento de Engenharia Civil, Universidade Federal de Pernambuco, Recife, PE, Brazil. e-mail: alinecatia.catia@gmail.com. Stela Fucale, D.Sc., Associate Professor, Programa de Pós-Graduação em Engenharia Civil, Universidade de Pernambuco, Recife, PE, Brazil. e-mail: sfucale@ poli.br. Silvio Romero de Melo Ferreira, D.Sc., Full Professor, Departamento de Engenharia Civil, Universidade Federal de Pernambuco, Recife, PE, Brazil. e-mail: sr.mf@hotmail.com.

Submitted on May 11, 2019; Final Acceptance on April 22, 2020; Discussion open until September 30, 2020.

DOI: $10.28927 /$ SR.432191 


\section{Materials and Methods}

The soil used comes from the Barreiras Formation located in the state of Pernambuco, in Northeastern Brazil. It is poorly graded (Fig. 1), has high plasticity, is classified as clayey sand according to the UCS (Unified Classification System) and is of type (A-7-6) in the TRB (Transportation Research Board) system, as shown in Table 1.

The rubber tire fibers were supplied by a local distributor in Pernambuco, with sizes ranging from 0.1 to $37 \mathrm{~mm}$ and average diameter of $1.07 \mathrm{~mm}$ (Fig. 2), and are sourced

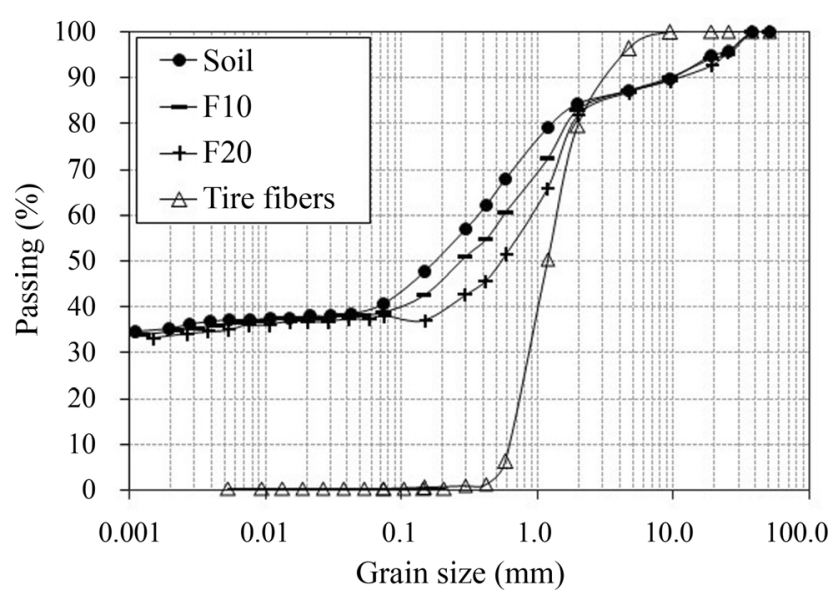

Figure 1 - Granulometric distribution curves for soil, tire fibers, and soil-fiber mixtures. from the process of retreading unwanted tires. The particle size distribution of the fibers indicates the absence of fine particles $(\%<0.075 \mathrm{~mm})$, Fig. 1, a specific gravity of 1.12 and a water absorption of $6.9 \%$, Table 1 . The addition of fibers to the soil practically does not change the granulometry and plasticity of the mixtures, falling under the UCS classification as clayey sands (SC) and classified as a clayey material (A-7-6) by the TRB, but with lower specific gravities than soil alone, Table 1.

The fibers were added to the soil in two proportions, $10 \%$ and $20 \%$ by dry soil weight, in a random and homo-

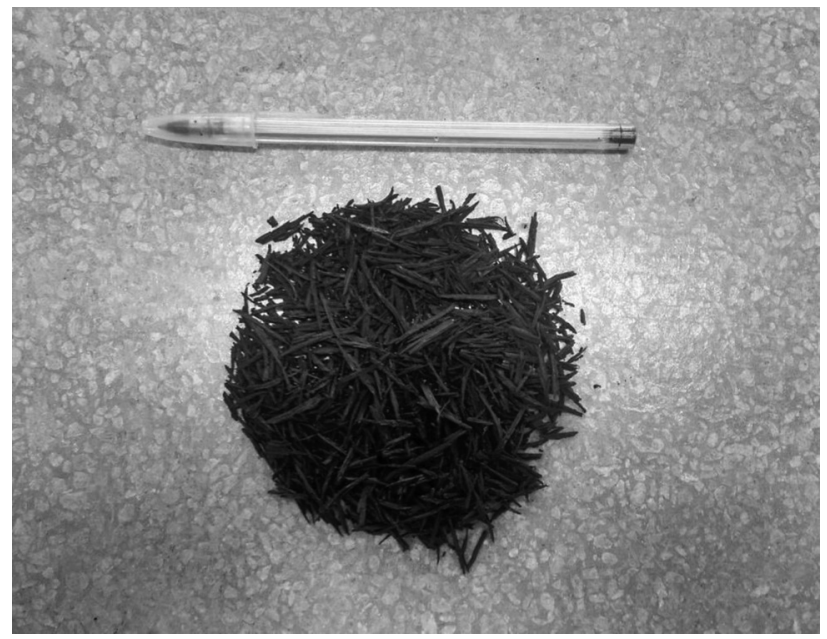

Figure 2 - Tire fibers utilized in the study.

Table 1 - Geotechnical properties of soil, tire fibers, and soil-fiber mixtures.

\begin{tabular}{|c|c|c|c|c|c|}
\hline \multirow[t]{2}{*}{ Parameters } & & \multicolumn{4}{|c|}{ Sample } \\
\hline & & Soil & F10 & $\mathrm{F} 20$ & Tire Fibers \\
\hline \multirow[t]{4}{*}{ Particle size $(\%)$} & $\phi>4.75 \mathrm{~mm}^{*}$ & 13 & 13 & 13 & 4 \\
\hline & $0.075 \mathrm{~mm}>\phi \leq 4.75 \mathrm{~mm}^{*}$ & 46 & 50 & 51 & 96 \\
\hline & $0.005 \mathrm{~mm}>\phi \leq 0.075 \mathrm{~mm}^{*}$ & 3 & 1 & 1 & 0 \\
\hline & $\phi \leq 0.005 \mathrm{~mm}^{*}$ & 38 & 36 & 35 & 0 \\
\hline $\mathrm{Cc}$ & & - & - & - & 0.9 \\
\hline $\mathrm{Cu}$ & & - & - & - & 2.2 \\
\hline Liquidity limit (\%) & & 44 & 47 & 46 & - \\
\hline Plasticity limit (\%) & & 23 & 25 & 26 & - \\
\hline Plasticity index (\%) & & 21 & 22 & 20 & - \\
\hline Water absorption (\%) & & - & - & - & 6.9 \\
\hline Specific gravity & & 2.66 & 2.29 & 1.98 & 1.12 \\
\hline Optimal moisture (\%) & & 17.5 & 16.4 & 16.1 & - \\
\hline Maximum dry specific weight $\left(\mathrm{kN} / \mathrm{m}^{3}\right)$ & & 17.6 & 16.1 & 14.8 & - \\
\hline Void ratio & & 0.51 & 0.43 & 0.33 & - \\
\hline UCS classification & & $\mathrm{SC}$ & $\mathrm{SC}$ & $\mathrm{SC}$ & SP \\
\hline TRB classification & & A-7-6 & A-7-6 & A-7-6 & A-1-b \\
\hline
\end{tabular}

(*) - description according to D 422-63 (ASTM 2007). 
geneous manner. These mixtures are referred to as F10 and F20, respectively. The contents were chosen in light of studies carried out by Macedo et al. (2016), who indicated that more satisfactory results were found for values below $30 \%$.

The soil and fiber-soil mixture test specimens were prepared at optimum moisture, by inserting distilled water corresponding to the optimum content for each material, and compacted to achieve at the maximum dry specific weight previously obtained in the normal Proctor test.

The molding of the test specimens for Scanning Electron Microscopy (SEM) and direct shear tests consisted in dividing the samples into two equal parts, which were statically compacted in a steel mold (Fig. 3) using a press. This procedure was necessary due to the impossibility of compacting the samples directly inside the shear box. The compaction was performed in such a way that the desired size was obtained exactly, with a 15-min wait period following this step for volumetric stabilization of the test specimens, allowing the mixtures to achieve the specific weight required. The test specimens for the permeability test were molded according to the normal Proctor test.

The analysis of the microstructure was performed using the SEM technique on air-dried samples fixed onto a metallic base (with a diameter of $75 \mathrm{~mm}$ and an approximate height of $10 \mathrm{~mm}$ ) with a carbon double-sided tape, and metalized with carbon inside a Cressington Carbon Coater 108 Carbon/Vacuum bell. A JEOL-brand electron scanning microscope was used, operating at $30 \mathrm{kV}$. From the soil and from each soil-fiber mixture, three samples were metallized, observed and analyzed. The surface of each sample was observed and images representative of the microstructures were selected.

The direct shear tests were carried out using test specimens with dimensions of $100 \times 100 \mathrm{~mm}$ and a height of $40 \mathrm{~mm}$, consolidated under normal stresses of 50, 100, 150 and $200 \mathrm{kPa}$, according to standard D 3080 (ASTM, 2011). The shear speed was $0.083 \mathrm{~mm} / \mathrm{min}$, the load cell capacity is $5 \mathrm{kN}$, and the displacements were measured by means of LVDT (Linear Variable Differential Transformer) type transducers, having a sensitivity of $0.001 \mathrm{~mm}$.

The permeability tests of the soil and the mixtures were carried out using permeameters of variable load, ac-

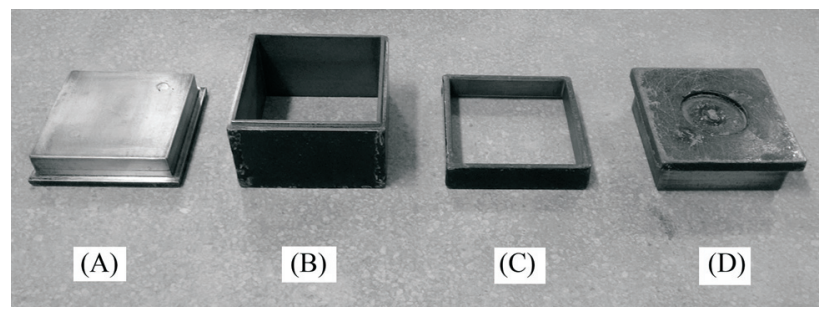

Figure 3 - Steel mold consisting of: base (a), box (b), collar (c), and lid (d). cording to the recommendations of standard NBR 14545 (ABNT, 2000), and for specimens with approximately $100 \mathrm{~mm}$ diameter and $127 \mathrm{~mm}$ height.

\section{Results and Discussions}

The microstructure, shear strength and permeability of soil and mixtures are presented and discussed.

\subsection{Analysis of shear strength}

The graphs showing shear stress $v s$. horizontal displacement of the clayey sand exhibit plastic-like behaviors at stress of $50 \mathrm{kPa}$ and plastic with stiffening at higher stresses (100, 150 and $200 \mathrm{kPa})$, Fig. 4. The mixture F10 presents a slight peak behavior at stresses of 50 and $100 \mathrm{kPa}$ and a plastic response at $150 \mathrm{kPa}$. The plastic response is also shown by the mixture F20 at 50 and $100 \mathrm{kPa}$. The soil-fiber mixtures exhibit soil-like behavior at a higher stress $(200 \mathrm{kPa})$.

The graphs for vertical displacement $v s$. horizontal displacement of the mixtures initially show compression followed by a subsequent dilation at all normal stresses applied, Fig. 4. As the fiber content increases, the onset of dilation and the magnitude of dilation occur for greater horizontal displacements, when compared with the soil.

The analysis of the shear strength for samples that did not show strength peaks was performed based on the criterion of De Campos \& Carrillo (1995). The fibers reduced the influence of rotational tension during the test and increased the soil rupture strength at all normal stress levels, indicating the force transfer from the soil matrix to the fibers and increased ductility in the mixtures. The fibers tend to be more mobilized under high tension, requiring greater horizontal displacements for more significant contributions to soil strength.

The friction angle of compacted clayey sand is $29^{\circ}$ and it has a cohesion of $10 \mathrm{kPa}$ (Table 2). The shear strength of the soil was increased by up to $47 \%$ when adding $10 \%$ tire fibers, while the addition of $20 \%$ fibers reduced the shear strength of the mixture in relation to the $10 \%$ fiber mixture, though it was still higher than of the soil alone. The interaction between the phases of the mixtures (Fig. 5) shows that the volume of soil interacting with $10 \%$ of fibers is greater than that in the mixture with $20 \%$ fibers. The electromicrography (section 3.3) also shows a lower interaction between soil and fibers in the $20 \%$ mixture, resulting in a lower shear strength.

\subsection{Hydraulic conductivity}

The average hydraulic conductivity of the saturated clayey sand was $9.31 \times 10^{-10} \mathrm{~m} / \mathrm{s}$, indicating low permeability. There are linear relationships between the variation of the fiber content (Fig. 6a), the void ratio of the mixtures (Fig. 6b) and the hydraulic conductivity coefficient. The incorporation of tire fibers into the soil resulted in a significant increase in the permeability of the mixtures, varying 

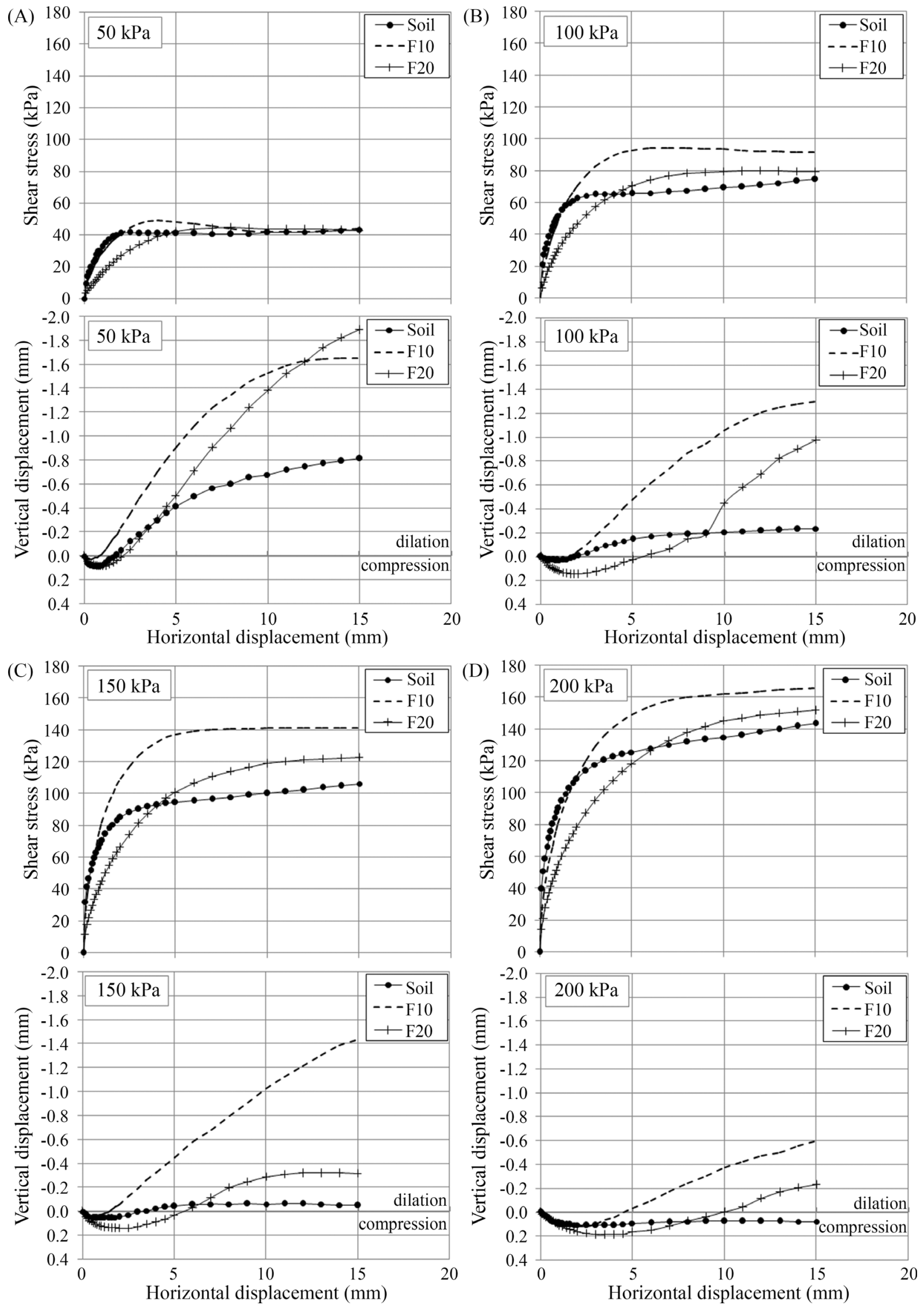

Figure 4 - Results from direct shear tests for: $50 \mathrm{kPa}(\mathrm{a}), 100 \mathrm{kPa}(\mathrm{b}), 150 \mathrm{kPa}$ (c), and $200 \mathrm{kPa}$ (d). 
Table 2 - Shear strength parameters.

\begin{tabular}{|c|c|c|c|c|}
\hline \multirow[t]{2}{*}{ Parameters } & & \multicolumn{3}{|c|}{ Sample } \\
\hline & & Soil & $\mathrm{F} 10$ & F20 \\
\hline \multirow[t]{3}{*}{$\sigma_{n}=50 \mathrm{kPa}$} & $\sigma_{n \text { corrected }}(\mathrm{kPa})$ & 53.14 & 52.05 & 54.27 \\
\hline & $\tau_{\text {rup }}(\mathrm{kPa})$ & 40.95 & 49.04 & 44.57 \\
\hline & $\varepsilon_{r u p}(\mathrm{~mm})$ & 7.0 & 4.0 & 8.0 \\
\hline \multirow[t]{3}{*}{$\sigma_{n}=100 \mathrm{kPa}$} & $\sigma_{n \text { corrected }}(\mathrm{kPa})$ & 106.28 & 107.40 & 110.92 \\
\hline & $\tau_{r u p}(\mathrm{kPa})$ & 66.02 & 94.34 & 79.53 \\
\hline & $\varepsilon_{r u p}(\mathrm{~mm})$ & 6.0 & 7.0 & 10.0 \\
\hline \multirow[t]{3}{*}{$\sigma_{n}=150 \mathrm{kPa}$} & $\sigma_{n \text { corrected }}(\mathrm{kPa})$ & 159.41 & 162.82 & 166.38 \\
\hline & $\tau_{r u p}(\mathrm{kPa})$ & 95.75 & 140.79 & 119.00 \\
\hline & $\varepsilon_{r u p}(\mathrm{~mm})$ & 6.0 & 8.0 & 10.0 \\
\hline \multirow[t]{3}{*}{$\sigma_{n}=200 \mathrm{kPa}$} & $\sigma_{n \text { corrected }}(\mathrm{kPa})$ & 212.55 & 217.09 & 221.83 \\
\hline & $\tau_{r u p}(\mathrm{kPa})$ & 128.18 & 159.94 & 145.24 \\
\hline & $\varepsilon_{r u p}(\mathrm{~mm})$ & 6.0 & 8.0 & 10.0 \\
\hline Cohesion intercept $(\mathrm{kPa})$ & & 10 & 18 & 12 \\
\hline Friction angle (degrees) & & 29 & 34 & 31 \\
\hline $\mathrm{R}^{2}$ & & 0.99 & 0.97 & 0.99 \\
\hline
\end{tabular}

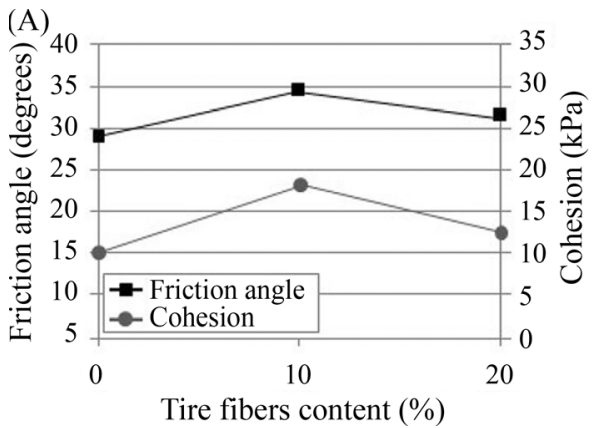

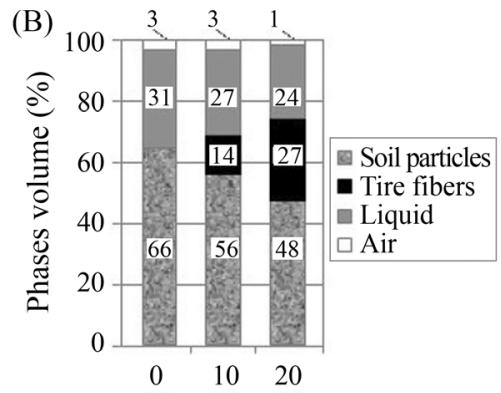

Tire fibers content $(\%)$

Figure 5 - Variation of the friction angle and cohesion with fiber content (a) and phase volume for each material (b).

Hydraulic coeficient $(\mathrm{m} / \mathrm{s})$ 1E-10 1E-09 1E-08 1E-07 1E-06 1E-05

(A)

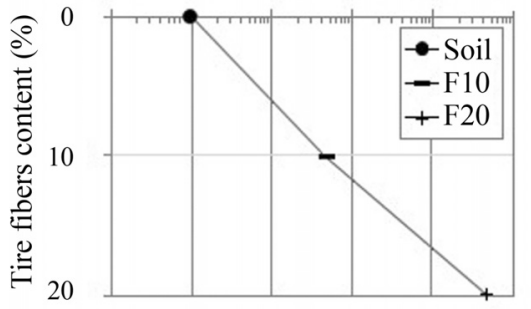

(B)

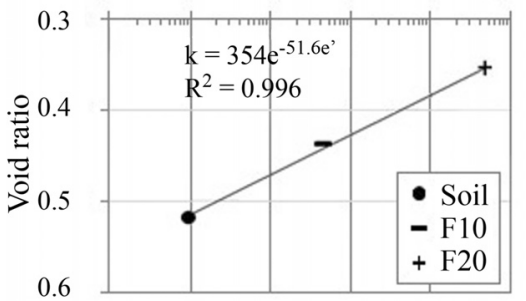

Figure 6 - Variation of the hydraulic coefficient with tire fiber content (a) and with the void ratio (b). from $10^{-10} \mathrm{~m} / \mathrm{s}$ to values on the order of $10^{-6}$ and $10^{-8} \mathrm{~m} / \mathrm{s}$ (Fig. 6a), increasing the order of hydraulic conductivity more than 10000 times. It should be noted that there is a reduction in the void ratio for the mixtures due to the insertion of the fibers, different from that occurring for soils (Fig. 6b).

The permeability test results are due to the lower quantity of soil (Fig. 5b) and to the canaliculi existing in the mixtures, caused by the presence of the fibers and larger pores in the soil-fiber contact (macropores). These macropores allow the water to percolate more easily, due to the smaller hydraulic head loss suffered by the water when percolating macrostructure, than among the soil particles (micropores). In this way, the hydraulic conductivity of the macrostructure is of greater importance than that of the microstructure. 


\subsection{Microstructural analysis}

The compacted clayey sand is structured into flakes formed by the arrangement of sand grains interconnected by silt and clay particles of dense form (Fig. 7) due to the compaction process, giving the soil a low permeability.

The tire fibers are of different sizes and they are randomly arranged within the soil matrix. On the surface of the soil mixture with $10 \%$ of tire fibers cracks (canaliculi) can be seen (Fig. 8), indicating the presence of the fibers due to it is elastic relaxation. The insertion of $10 \%$ fibers altered the surface appearance of the sample, but it can be inferred that there is intense interaction between the tire particles and the clayey sand matrix, explaining the mechanical results obtained.

In the soil mixture with $20 \%$ tire fibers, two different situations are verified (Fig. 9a) in the same electromicrograph: a tire fiber partially adhered to the soil matrix with visible voids (macropores) at the interface (Fig. 9c), and a tire fiber completely enveloped by the soil, without a clear separation zone (Fig. 9b), showing that the presence of the fibers does not completely fragilize the structure, matching up with the results from the mechanical tests, indicating that the adhesion between the two materials is sufficient to improve the strength of the mixture.

\section{Conclusions}

The use of alternative materials as soil reinforcement have been increasingly encouraged in geotechnical engineering. In this article, the influence of tire rubber fibers on the hydromechanical behavior of a soil from Barreiras Formation was investigated. The shear strength, permeability and microstructure of the samples were evaluated. A microstructural analysis was correlated with hydromechanical responses. The following conclusions can be draw:

The tire fibers increased the shear strength of the clayey sand by up to $47 \%$ for the mixture containing $10 \%$ tire fibers and with the applied normal stress increased. The fibers have a high capacity to absorb the energy of deformation applied to the soil. The good mechanical performance found in the soil-fiber mixtures can be attributed to the improved fiber-matrix interaction and the fiber content incorporated into the soil.

The tire residues improved the hydraulic properties of the soil, increasing the hydraulic conductivity by more than 10000 times, this aspect being associated with the effect of the microstructure of the tire fibers on the soil matrix, which provide preferential paths for water percolation and lower head loss, and dependent on the applications of the soil-fibers mixtures.
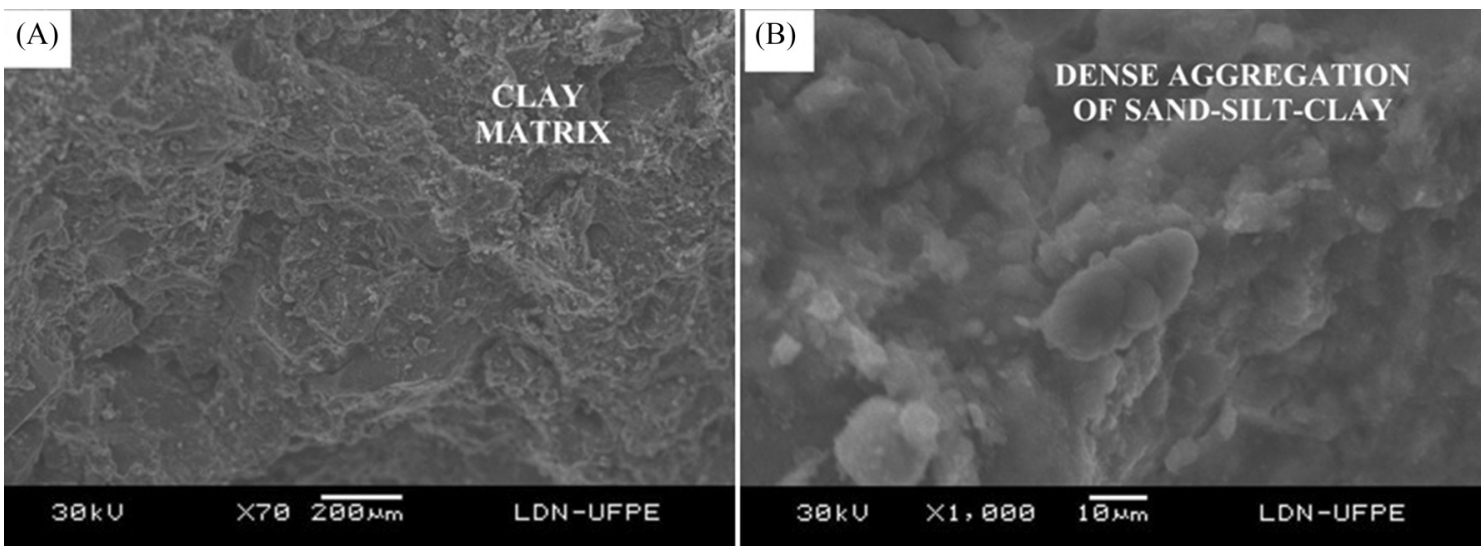

Figure 7 - Electromicrographs of clayey sand at magnifications of $70 \times(a)$ and $1000 \times(b)$.
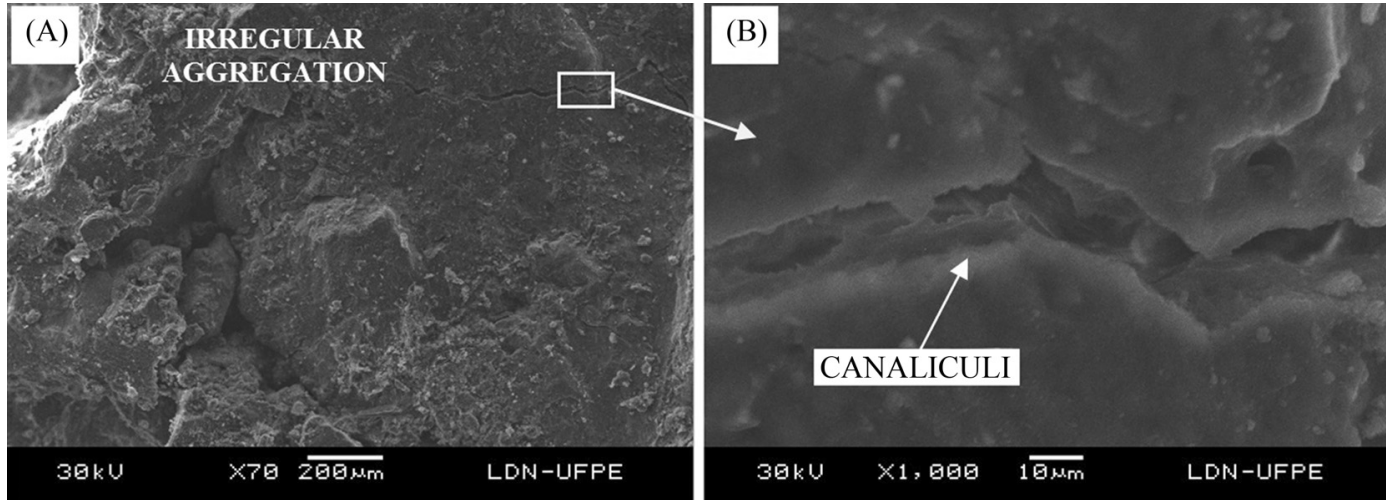

Figure 8 - Electromicrographs of F10 mixture at magnifications of $70 \times$ (a) and $1000 \times$ (b). 

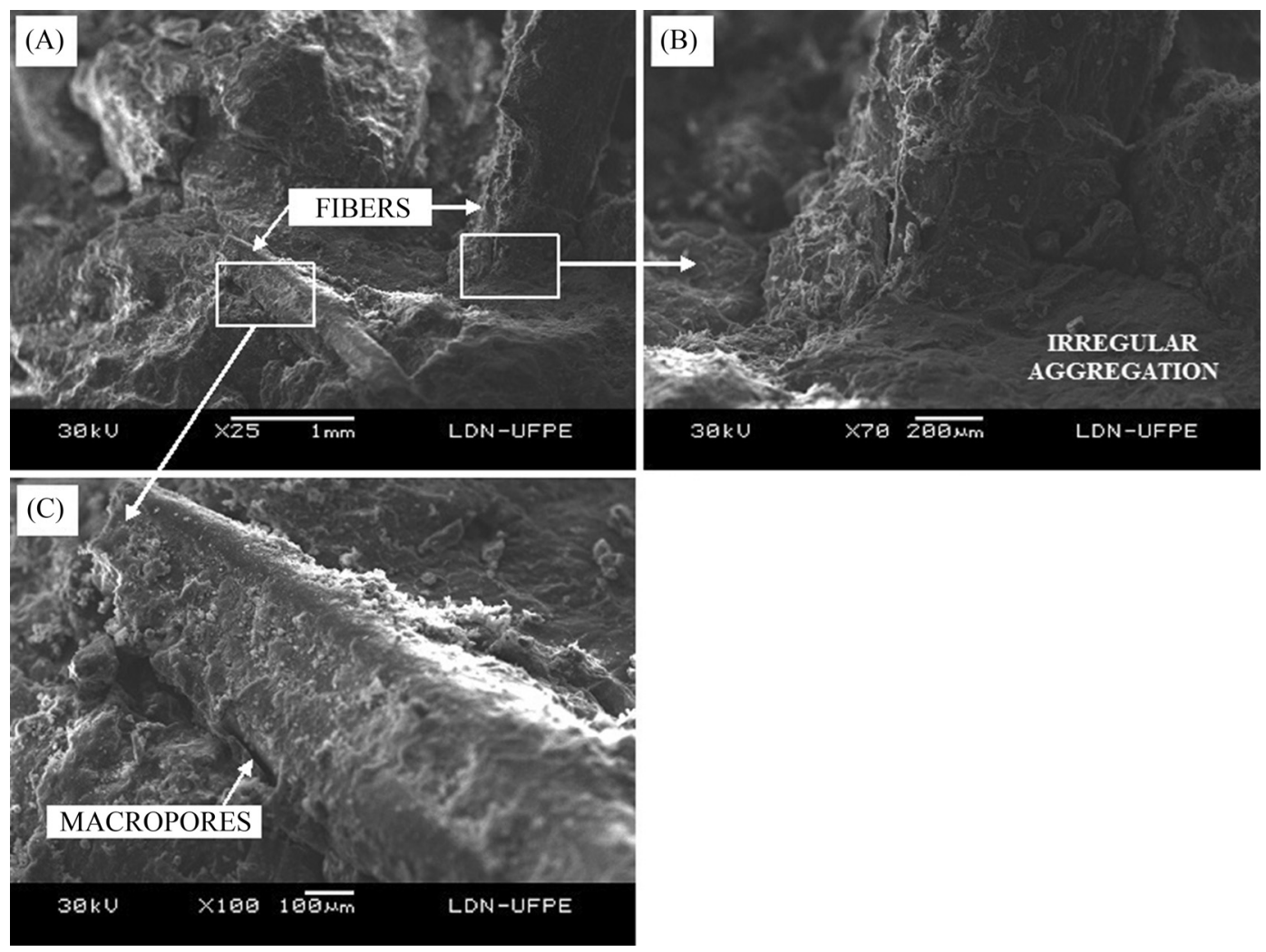

Figure 9 - Electromicrographs of F20 mixture at magnifications of 25× (a), 70× (b), and 100× (c).

The incorporation of tire fibers, in addition to improvements brought to the soil, also promotes environmental benefits by giving a proper destination for this type of alternative material, reducing what is ordinarily an environmental liability.

\section{Acknowledgments}

The authors would like to acknowledge the program for academic strengthening of University of Pernambuco for the financial support.

\section{References}

ABNT (2000). Soil - Determination of the Coefficient of Permeability of Clay Soils- NBR 14545. Brazilian Association of Technical Standards, Rio de Janeiro, Brazil, $12 \mathrm{p}$.

Anvari, S.M.; Shooshpasha, I. \& Kutanaei, S. (2017). Effect of granulated rubber on shear strength of finegrained sand. Journal of Rock Mechanics and Geotechnical Engineering, 9(5):936-944. https://doi.org/10.1016/j.jrmge.2017.03.008

ASTM (2011). Standard Test Method for Direct Shear Test of Soils Under Consolidated Drained Conditions- D 3080. ASTM International, West Conshohocken, Pennsylvania, USA, 9 p.
ASTM (2007). Standard Test Method for Particle Size Analysis of Soils - D 422-63. ASTM International, West Conshohocken, Pennsylvania, USA, 8 p.

Balunaini, U.; Mohan, V.K.D.; Prezzi, M. \& Salgado, R. (2014). Shear strength of tyre chip-sand and tyre shredsand mixtures. Proceedings of the Institution of Civil Engineers - Geotechnical Engineering, 167(6):585-595. https://doi.org/10.1680/geng.13.00097

Bosscher, J.; Edil, T.B. \& Kuraoka, S. (1997). Design of highway embankments using tire chips. Journal of Geotechnical and Geoenvironmental Engineering, ASCE, 123(4):295-304.

https://doi.org/10.1061/(ASCE)1090-0241(1997)123:4 (295)

De Campos, T.M.P. \& Carrillo, C.W. (1995). Direct shear testing on an unsaturated soil from Rio de Janeiro. Proc. Int. Conf. on Unsaturated Soils, UNSAT'95, Balkema, Paris, pp. 31-38.

Edinçliler, A. \& Ayhan, V. (2010). Influence of tire fiber inclusions on shear strength of sand. Geosynthetics International, 17(4):183-192.https://doi.org/10.1680/gein.2010.17.4. 183

Edinçliler, A. \& Cagatay, A. (2013). Weak subgrade improvement with rubber fibre inclusions. Geosynthetics 
International, https://doi.org/10.1680/gein.12.00038

ETRA (European Tyre Recycling Association). (2013). Introduction to Tyre Recycling: 2013 (Twenty Years of Tyre Recycling in the EU). Available at http://www.etra-eu.org/joomla/publicationsand accessed on July 14th 2017.

ETRMA (European Tyre \& Rubber Manufacturers' Association). (2011). End of Life Tyres - A Valuable Resource with Growing Potential. Available at http://www.etrma.org/uploads/Mod-

ules/Documentsmanager/brochure-elt-2011-final.pdf and accessed on July 14th 2017.

Fu, R.; Coop, M.R. \& Li, X.Q. (2014). The mechanics of a compressive sand mixed with tyre rubber. Géotechnique Letters, 4(3):238-243. https://doi.org/10.1680/geolett.14.00027

Hazarika, H.; Yasuhara, K.; Kikuchi, Y.; Karmokar, A.K. \& Mitarai, Y. (2010). Multifaceted potentials of tirederived three-dimensional geosynthetics in geotechnical applications and their evaluation. Geotextiles and Geomembranes, 28(3):303-315. https://doi.org/10.1016/j.geotexmem.2009.10.011

Indraratna, B.; Sun, Q.; Heitor, A. \& Grant, J. (2018).Performance of rubber tire-confined capping layer under cyclic loading for railroad conditions. Journal of Materials in Civil Engineering, ASCE, 30(3):06017021. https://doi.org/10.1061/(ASCE)MT.1943-5533.00021 99

Kaushik, M.K.; Kumar, A. \& Bansal, A. (2015). Performance assessment of gravel -Tire chips mixes as drainage layer materials using real active MSW landfill leachate. Geotechnical and Geological Engineering, 33(4):1081-1098. https://doi.org/10.1007/s10706-015-9889-1

Macedo, M.C.; Fucale, S. \& Ferreira, S.R.M. (2016). Geomechanical behavior of soil mixtures with tire residues and construction and demolition waste. Electronic Journal of Geotechnical Engineering, 21(19):6393-6410.

Moghadam, M.J.; Zad, A.; Mehrannia, N. \& Dastaran, N. (2018). Experimental evaluation of mechanically stabilized earth walls with recycled crumb rubbers. Journal of Rock Mechanics and Geotechnical Engineering, 10(5):947-957. https://doi.org/10.1016/j.jrmge.2018.04.012

Özkul, Z.H. \& Baykal, G. (2007). Shear behavior of compacted rubber fiber-clay composite in drained and undrained loading. Journal of Geotechnical and Geoenvironmental Engineering, ASCE, 133(7):767781.
https://doi.org/10.1061/(ASCE)1090-0241(2007)133:7 (767)

Reddy, S.B. \& Krishna, A.M. (2017). Tyre chips as compressible inclusions in earth-retaining walls. Proceedings of the Institution of Civil Engineers - Ground Improvement, 170(3):137-148. https://doi.org/10.1680/jgrim.16.00034

RMA (Rubber Manufacturers Association) (2014). 2013 U.S. Scrap Tire Management Summary. Rubber Manufacturers Association, Washington, D.C., pp. 1-18.

Sellaf, H.; Trouzine, H.; Hamhami, M. \& Asroun, A. (2014). Geotechnical properties of rubber tires and sediments mixtures. Engineering, Technology \& Applied Science Research, 4(2):618-624.

SEST SENAT (Serviço Social do Transporte/Serviço Nacional de Aprendizagem do Transporte) (2017). Cerca de 450 mil toneladas de pneus são descartados por ano no

Brasil.Available http://www.sestsenat.org.br/imprensa/noticia/cerca-de450-mil-toneladas-de-pneus-sao-des

cartados-por-ano-no-brasil and accessed on July 14th 2017.

Tafreshi, S.N.M.; Mehrjardi, G.T. \& Dawson, A.R. (2012). Buried pipes in rubber-soil backfilled trenches under cyclic loading. Journal of Geotechnical and Geoenvironmental Engineering, ASCE, 138(11):1346-1356. https://doi.org/10.1061/(ASCE)GT.1943-5606.0000710

Veiga, C.J.V. (2014). Mapeamento da Formação Barreiras na Região Norte Fluminense, entre os Rios Paraíba do Sul e Itabapoana. Trabalho Final de Curso (Geologia), Departamento de Geologia, Instituto de Geociências, Universidade Federal do Rio de Janeiro, Rio de Janeiro, $49 \mathrm{p}$.

Xu, O.; Rangaraju, P.R.; Wang, S. \& Xiao, F. (2017). Comparison of rheological properties and hot storage characteristics of asphalt binders modified with devulcanized ground tire rubber and other modifiers. Construction and Building Materials, 154:841-848. https://doi.org/10.1016/j.conbuildmat.2017.07.221

\section{List of Symbols}

$\Phi$ : the particle size

$\sigma_{n}$ : the normal stress

$\sigma_{n \text { corrected }}$ : the corrected normal stress

$\tau_{r u p}:$ the shear rupture stress

$\varepsilon_{r p p}:$ the rupture deformation

$\mathrm{R}^{2}$ : the coefficient of determination

$k$ : the hydraulic coefficient

$e^{\prime}$ : the void ratio

F10: mixture having $10 \%$ tire fibers

F20: mixture having $20 \%$ tire fibers 